\title{
Visual Basic for Application Excel For Creativity Thinking Skills and Student Disposition on Kapita Selekta
}

\author{
Martin Bernard $^{1}$, Anik Yuliani ${ }^{2}$, Nelly Fitriani $^{3}$, Sri Adi Widodo ${ }^{4}$ \\ pamartin23rnar@gmail.com¹, anik_yuliani0407088601@ikipsiliwangi.ac.id ${ }^{2}$, \\ nellyfitriani@ikipsiliwangi.ac.id ${ }^{3}$, sriadi@ustjogja.ac.id ${ }^{4}$ \\ 1,2,3 IKIP Siliwangi, Cimahi, Indonesia \\ ${ }^{2}$ Universitas Sarjanawiyata Tamansiswa, Yogyakarta, Indonesia
}

\begin{abstract}
Basic math is a prerequisite that must be met by students of mathematics education to facilitate mastery of mathematical concepts. To develop creative ideas and disposition of their students need some way of students to solve mathematical problems called premises Open Ended approach and the help of ICT for visualizing accurate answers by using Visual Basic for Applications for Microsoft Excel. To see the effectiveness of the study, researchers conducted experiments on three groups or three grade Student of 2015 at the Teachers' Training College Siliwangi, and found that learning in subjects capita selekta junior high school, groups using Open Ended approaches with VBA-supported Microsoft Excel are better than those who use and not use VBA for Microsoft Excel, as well as VBA for Microsoft Excel as a useful application for creating and explaining mathematical concepts compared to without VBA for Microsoft Excel.
\end{abstract}

Keywords: Creative Ability, Disposition, Open-Ended, VBA for Microsoft Excel

\section{Introduction}

Mathematics is the essential basis of the foundation that must be mastered by the student to broaden the mastery of mathematical concepts further. Therefore, basic math is needed by students to make sense of mathematical concepts well, using the skills students bring new ideas to relate math to real objects. This is consistent with Johnson [1] that the numerical mastery factor Importance of math skills to the student's performance in a quantitative discipline. That the constraints faced by the students have not led to the idea to create a visual tool for understanding math concepts, as a result of students not able to Understand the concepts of mathematics this is found in the classroom $82.4 \%$ Students have not been able to associate images with mathematics and $75.4 \%$ of students have not been able to define the number and geometry of one determines the prime number. It can be seen from the data PISA 2015 that Indonesia ranks 63 out of 70 countries [2], which is the smallest value among the scores of mathematics (386) than science (403) and reading (397). Efforts must be made how to develop the creative abilities of students towards mathematics that produces a variety of ways the discovery of new ideas the students when facing mathematical problems to provide 
appropriate solutions. The goal is not focused on the search for answers, but more emphasis tread arrive at a response[3].

To foster creative ideas of students would need a visualization tool as a replacement props mathematics more effectively to help make the process of the answer to solve the problem or open-ended approach to one based on ICT is Visual Basic application for Microsoft Excel. Because Visual Basic Application for Excel can help students' understanding of fundamental mathematics [4]. There are some essential things part of learning to use ICT is the effectiveness of the current time and the place to learn more math support [5], and ICT is also useful to know how to build knowledge and information about the involvement of the prospective teachers with secondary school students in the field [6].

The purpose of this study is not only to use the knowledge of basic mathematics but also how to deliver students as prospective teachers to students in secondary schools, in accordance with the opinion of Collis [7] ICT is able to make a prediction and selection strategies undertaken by students at colleges in accordance with the development of external activities in education and can be applied to the internal policy that can be distributed to all students or prospective teachers.

By using the approach of Open-Ended and aided Visual Basic Application for Microsoft Excel in addition to developing the creative abilities of students, it can also improve the strength of the disposition of which is to increase self-confidence to be able to express their ideas, honesty in the ability of knowledge, responsible way to resolve problem solving, and hard work always to try to get the best results and the apparent experienced by the students themselves in accordance with the opinion of Bernard [5].

\section{Research Methods}

Research method conducted in two classes of the first class is a class that is learning to use by using that develop creative abilities of students with the approach of Open-Ended with assisted Visual Basic Application for Microsoft Excel and the second class is the class that the development of creative skills of students in the usual way with supported Visual Basic Application for Microsoft Excel and the third class is a class that uses the usual way with a quasi-experimental research design. Both categories use ICT as a tool to create props mathematics applied to subjects capita selekta middle school math samples taken for the first class consisted of 31 students and for the second class consists of 36 students, and a third class includes of 33 students.

\section{Results and Discussion}

From the results of the pretest or before learning about the exam conducted creative abilities of students with basic knowledge of mathematics courses capita selekta middle school math to group 1, group 2 and group 3 .

Table 1. Data Description pretest for Three Groups

\begin{tabular}{cccc}
\hline NO & GROUP & $\bar{x}$ & $\mathrm{~S}$ \\
\hline 1 & Group 1 & 6.19 & 1.66 \\
2 & Group 2 & 6.28 & 1.79 \\
3 & Group 3 & 6.64 & 1.19 \\
\hline
\end{tabular}

From table 1, it shows that group 3 has a larger average compared to group 1 and group 2 and group 3 has smaller deviation deviations compared to group 1 and group 2 which means that the three group students are more evenly distributed. Based on the average scores in each group that group 1 was given the Open-Ended approach aided by Visual Basic Application for Excel, group 2, the usual way of teaching assisted Visual Basic Application for Excel and group 
3 Unassisted Learning Visual Basic for Microsoft Excel. The decision whether there is a third difference in the average value of the class or not, then the thing to do is a test of normality.

To test for normality for all three groups, can be seen in Table 2, where the significant value of group 1, group 2 and group 3 respectively $0.010,0.000$, and 0.000 concluded that the considerable amount of the three groups is less than 0.05 , which means the three data is not standard. If the information is not usual group then continued with an average difference of nonparametric Kruskal Wallis test.

Tabel 2. Pretest Test Data Third Normal

\begin{tabular}{llcccccc}
\hline Kelas & & \multicolumn{3}{c}{ Kolmogorov-Smirnov $^{\mathrm{a}}$} & \multicolumn{3}{c}{ Shapiro-Wilk } \\
& & Statistic & df & Sig. & Statistic & df & Sig. \\
\hline Value & Group 1 & .183 & 31 & .010 & .905 & 31 & .009 \\
& Group 2 & .261 & 36 & .000 & .765 & 36 & .000 \\
& Group 3 & .236 & 33 & .000 & .929 & 33 & .033 \\
\hline
\end{tabular}

a. Lilliefors Significance Correction

Table 3. Kruskal Wallis for Third current group pretest

\begin{tabular}{lr}
\hline & Value \\
\hline Chi-Square & 3916. \\
df & 2 \\
Asymp Sig. & .141 \\
\hline a. Kruskal Wallis Test &
\end{tabular}

From the result of Table 3 shows the significant value of 0.141 is more significant than 0.05 , it can be concluded that the data of the three groups did not make any difference in the average value of the current class pretest.

Results of Table 4 shows that an increase in the average value of the three groups during the post-test and pretest, and group 1 was higher than in group 2 and group 3, and for the standard deviation of a group of 3 smaller than all of the groups, which means a group of 3 more evenly than the group 1 and group 2 .

Tabel 4. Test Normal Posttest Data Third

\begin{tabular}{llcccccc}
\hline Class & & \multicolumn{3}{c}{ Kolmogorov-Smirnov $^{\mathrm{a}}$} & \multicolumn{3}{c}{ Shapiro-Wilk } \\
& & Statistic & df & Sig. & Statistic & df & Sig. \\
\hline \multirow{2}{*}{ Value } & Group 1 & .146 & 31 & .090 & .955 & 31 & .216 \\
& Group 2 & .117 & 36 & .200 & .945 & 36 & .073 \\
& Group 3 & .140 & 33 & .097 & .956 & 33 & .202 \\
\hline
\end{tabular}

a. Lilliefors Significance Correction

Because of the three groups of fewer than 40 students of the significant value using the Kolmogorov-Smirnov, that group 1, group 2 and group 3 respectively have a considerable benefit of $0.90,0.200$, and 0.097 and the third value greater than 0.05 means that the data usual third. 
Table 5. Test Homogeneity of the Third Group Posttest

\begin{tabular}{cccc}
\hline Levene Statistic & DF1 & DF2 & Sig. \\
\hline 10576 & 2 & 97 & .060 \\
\hline
\end{tabular}

Table 6 shows the similar test of the three groups, and the results of significant value greater than 0.06 to 0.05 and the third means homogeneous the data and then proceed to test the average difference by using ANOVA one lane [7].

Table 6. ANOVA One Line to Third Group Posttest

\begin{tabular}{lrrrrr}
\hline & Sum of Squares & df & Mean Square & F & \multicolumn{1}{c}{ Sig. } \\
\hline Between Groups & 602779 & 2 & 301389 & 69944 & .000 \\
Within Groups & 417971 & 97 & 4,309 & & \\
Total & 1020.750 & 99 & & & \\
\hline
\end{tabular}

From the results of ANOVA one lane in Table 7, the significant value of 0.000 is less than 0.05 , which means the three groups the difference in the average cost of the class. If seen from Table 4, that the average group 1 was higher than that of all the group means that the group 1 is better than the group 2 and group 3 , while the second group is better than the group 3 . The average difference can be seen from the table group 8 .

Tabel 7. Test Tukey of the Third Group

\begin{tabular}{ccccccc}
\hline \multirow{2}{*}{ (I) Group } & \multirow{2}{*}{ (J) Group } & $\begin{array}{c}\text { Mean Difference } \\
\text { (I-J) }\end{array}$ & Std. Error & Sig. & \multicolumn{2}{c}{ 95\% Confidence Interval } \\
\cline { 6 - 7 } Group 1 & Group 2 & $4.157^{*}$ & .509 & .000 & 2.95 & Lower Bound \\
& Group 3 & $6.008^{*}$ & .519 & .000 & 4.77 & Upper Bound \\
Group 2 & Group 1 & $-4.157^{*}$ & .509 & .000 & -5.37 & 7.24 \\
& Group 3 & $1.851^{*}$ & .500 & .001 & .66 & -2.95 \\
Group3 & Group 1 & $-6.008^{*}$ & .519 & .000 & -7.24 & 3.04 \\
& Group 2 & $-1.851^{*}$ & .500 & .001 & -3.04 & -4.77 \\
\end{tabular}

*. The mean difference is significant at the 0.05 level.

In table 8, explaining that the average difference using Tukey's test to see no difference on average in each of the two groups [7]. Namely group 1 and group 2, amounting to 4.157 with significant value 0,000 less than 0.05 , which means that there is an average difference between group 1 and group 2 or group 1 is better than group 2 . in the same way the average difference in group 1 and group 3 was 6.008 with significant value 0,000 less than 0.05 means the difference in the mean average between group 1 and group 3 , in which the first group is better than group 3. and for the average difference in group 2 and group 3, it was found that the average difference value to two groups is significant value $0,0011,851$ to less than 0.05 , meaning that the average difference between group 2 and group 3 where group 2 is better than group 3 .

For questionnaires dispositions and grades of students based on low, medium and high levels, it can be concluded that small and low questionnaires have three students and no high-value surveys. For students who rated top polls and have high scores, there are three students and no students who have high ratings and assess 
Table 8. Disposition Questionnaire Students Against Value

\begin{tabular}{llcccc}
\hline & & Values & & Total \\
\cline { 3 - 6 } & & Low & Medium & High & \\
\hline Questionnaire & low & 3 & 1 & 0 & 4 \\
& medium & 0 & 18 & 2 & 20 \\
\multirow{2}{*}{ Total } & high & 0 & 4 & 3 & 7 \\
& & 3 & 23 & 5 & 31 \\
\hline
\end{tabular}

the low questionnaire. For the questionnaire assessment by high students more than the evaluation of the student, inquiries are small as well as higher student scores higher than low student scores.

Table 9. chi-squared test

\begin{tabular}{lccr}
\hline & Value & df & \multicolumn{2}{c}{ Asymp. Sig. (2-sided) } \\
\hline Pearson Chi-Square & $26714^{\mathrm{a}}$ & 4 & .000 \\
Likelihood ratio & 18926 & 4 & .001 \\
Linear-by-Linear Association & 11999 & 1 & .001 \\
N of Valid Cases & 31 & & \\
\hline a. Seven cells $(77.8 \%)$ have expected count less than 5. The minimum expected number is .39.
\end{tabular}

To see if there is an association or not the data is processed by using Chi-Square test with a significant value of 0.000 or less than 0.05 means that the questionnaire disposition to do with the student's scores. At first, the students tried to Visual Basic Application is fundamental, and run the appropriate program design related to basic mathematics, for example, determining the natural numbers, integers, odd and prime numbers. To develop the creative abilities of students, researchers conducted a study with the Open-Ended approach, in which researchers gave the problem by inserting a base image on the Insert menu and then selected Shapes of size and shape, and also needed some cell address as the condition setting numbers or configuration. From the form of ways, students will give a mathematical definition based design to shape the output of which is made.

The first phase, researchers gave the initial stimulus to the students about trying to make the set of natural numbers and integers, and the result of natural numbers names will appear on the address different cells. The initial step, researchers gave the students to make strides in the form of information related to the original number, and then collect data from each student. From the data associated with the Visual Basic Application for Microsoft Excel gradually up until the end and then the program is run.

The observation of the researchers of the students who performed those early experiments, it was found some validity students is $64.35 \%$ error in the writing of the language program, $53.76 \%$ error associate mathematical concept with Visual Basic Application for Microsoft Excel, $45.63 \%$ error gives the name identity shapes on Selection Pane and enter the code command in form through the Assign Macro. At this stage, the student still can not bring up new ideas.

The second phase, researchers gave students the opportunity to create integers, odd and even number. Students have already begun to make the concept definition and found no differences in the designs make odd and even numbers, using modulo function in Visual Basic Application. The first student, found in every cell number is divisible by two, then the name is an even number. Otherwise, it is an odd number. And the opinion of the student, believe what if every cell divided in two and remain one, then the name is a different number, and if not then the name is an even number. 
The results of observations of the second stage, the mistakes of students decreased in all three factors, $52.67 \%$ error in the writing of the language program, $5.78 \%$ error in associating the mathematical concept with Visual Basic Application for Microsoft Excel and $4.35 \%$ error gives identity shapes name on the Selection Pane. And keep in mind is a typing error occurred program language because students do not understand about the function logic such as If Then, Do While Loop, For the Next, Select Case and preparation of the algorithm. At this stage, seen from the $24.56 \%$ of the students have started to come up with ideas that will be created.

The third phase, researchers provide a mathematical problem, namely the challenge of primes, and generated $30.12 \%$ error in the writing of programming languages with their guidance, $4.46 \%$ error in associating the mathematical concept with Visual Basic Application for Microsoft Excel and provides error $2.32 \%$ shapes name identity on Selection Pane. In this phase, the students, bring new ideas as much as $57.35 \%$.

In the fourth phase, the researchers began giving merging commands by using Visual Basic for Microsoft Excel with Shapes with cells on sheets more. Then the researchers gave some of the images that will be designed by students into mathematics teaching aids media.

The first student is given a problem of problems related to secondary mathematics school is made about the number of arithmetic progression n-th term, and their task is to write down the relationship of the mathematical concepts in a given problem and after that student are given the opportunity of time to describe to the Visual Basic language, To take note of is to write down the identity of the object's name must be consistent during program execution.

Sub aritmetic1 ()

Dim a As Integer

Dim b As Integer

Dim c As Integer

$\mathrm{b}=0$

$\mathrm{c}=$ Range $(" \mathrm{C} 1 ")$

For $\mathrm{a}=1$ To $\mathbf{c}$

$$
\begin{aligned}
& \text { Range }(" A " \& 1+a)=a \\
& b=b+a \\
& \text { Range("B" \& } 1+a)=b
\end{aligned}
$$

Next a

End Sub

The second student makes a description of the similarities of the variables by using the buttons where there is the concept of identity and inverse operations of addition and subtraction. Then the storyline is designed to be formed into props aided by the Visual Basic Application for Excel.

Sub add1()

Dim sheet1 As Worksheet

Set sheet $1=$ Worksheets $(1)$ 


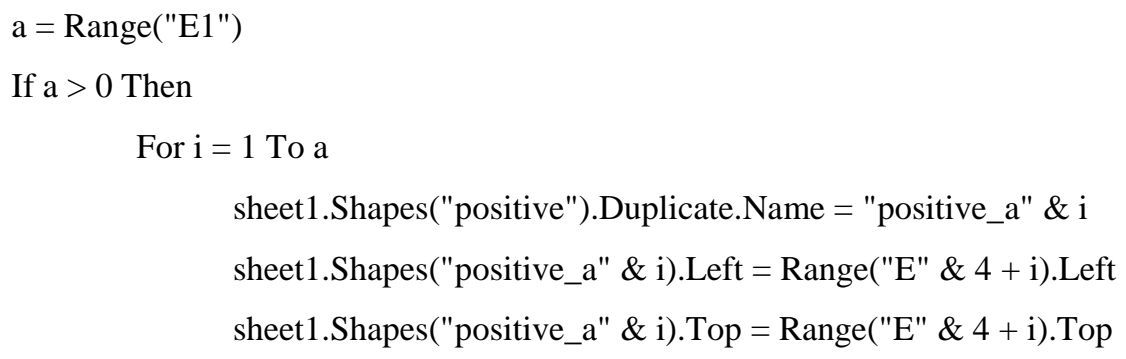

Else

If $\mathrm{a}<0$ Then

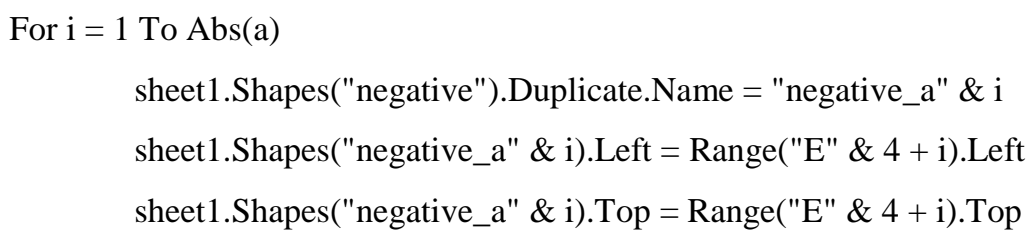

End If

End If

End Sub

Students should be able to design a picture before making a command to run the program one variable equation. And should be adjusted based on the storyline made, so for each of the shapes given the authority to display the new configurations to indicate the existence of variables and constants, after designing the desired image, create a new programming language Visual Basic Application for Microsoft Excel. Once this is done, then run the program from work produced.

\section{Conclusion}

From the research that the development of creative abilities of students with open-ended approach aided Visual Basic Application for Microsoft Excel is better than the usual method that supported or not assisted Application for Microsoft Visual Basic for Excel in capita selekta middle school math, and Visual Basic Application for Microsoft Excel is a substitute alternate media props to create a more active and interactive student to understand basic math.

\section{Acknowledgments}


Thanks to Rector IKIP Siliwangi who has given time and place to be a research and also support in the form of internal grant that is needed so that the making of mathematics tools based on ICT can be useful for students as prospective teachers and junior high school students, and thanks to the lecturers of education mathematics that provide meaningful input.

\section{References}

[1] M. Johnson, E. Kuennen, M. Johnson, and E. Kuennen, "Basic Math Skills and Performance in an Introductory Statistics Course Basic Math Skills and Performance in an Introductory Statistics Course," J. Stat. Educ., vol. 14, no. 2, 2006.

[2] Wardono, B. Waluya, Kartono, Mulyono, and S. Mariani, "Development of innovative problem based learning model with PMRI-scientific approach using ICT to increase mathematics literacy and independence- character of junior high school students Development of innovative problem based learning model with PMRI-sci," J. Phys. Conf. Ser. 983, vol. 983, no. 1, pp. 1-9, 2018.

[3] Y. N. Andriani and S. S. Madio, "PERBANDINGAN KEMAMPUAN BERPIKIR REFLEKTIF ANTARA SISWA YANG MENDAPATKAN PENDEKATAN OPEN ENDED DENGAN KONVENSIONAL,” Mosharafa, vol. 2, no. 2, pp. 135-144, 2013.

[4] S. Chotimah, M. Bernard, and S. M. Wulandari, "Contextual approach using VBA learning media to improve students' mathematical displacement and disposition ability Contextual approach using VBA learning media to improve students ' mathematical displacement and disposition ability," J. Phys. Conf. Ser., vol. 948, no. 1, pp. 1-10, 2018.

[5] M. Bernard, "Meningkatkan kemampuan komunikasi dan penalaran serta disposisi matematik siswa smk dengan pendekatan kontekstual melalui game adobe flash cs 4.0," vol. 4, no. 2, pp. 197-222, 2015.

[6] A. V. I. Hofstein and V. N. Lunetta, "The Laboratory in Science Education : Foundations for the Twenty-First Century," Sci. Educ., vol. 88, no. 1, pp. 28-54, 2004.

[7] A. J. Izenman, Modern Multivariate Statistic Techniques. Philadelphia: Springer, 2008. 